\title{
Lichen recolonization in the city of Torun
}

\author{
Edyta Adamska \\ Department of Plant Taxonomy and Geography,Institute of Ecology and Environment Protection, \\ Nicolaus Copernicus University, Gagarina 9, 87-100 Toruń, Poland \\ e-mail: adamska@umk.pl
}

\begin{abstract}
Together with the decreasing pollution load in the atmosphere, particularly with sulphur oxides, one can observe inhibition of the process of lichens' biota impoverishment in areas with the increased anthropopressure. Since the end of the 1970s, in most of the cities of Western Europe, the process of recolonization by lichens has been observed. Recently, this phenomenon has been described also in Poland. As a consequence of lichenological researches, carried out in the city of Torun between 2001 and 2010 , as well as based on the literature data, one can confirm the first symptoms of the process of recolonization by these organisms within the city area. In this paper, the most spectacular examples are presented in order to illustrate the early process of recolonization by epiphytic lichens in the city of Torun during the last 60 years.
\end{abstract}

Key words: air pollution, environmental monitoring, lichens, recolonization, $\mathrm{SO}_{2}$, Toruń, urban area.

\section{Introduction}

As emphasized by many authors, lichens are sensitive indicators of changes in habitat conditions, including air pollution (e.g.: Fałtynowicz 1995; Conti \& Cecchetti 2001; Nash 2008).

The phenomenon of lichens' response to changes in the atmospheric concentration of $\mathrm{SO}_{2}$ is described by e.g. Seaward (1997), according to whom an insignificant increase in $\mathrm{SO}_{2}$ concentration brings about a significant reduction in the species diversity, whereas even high reduction of $\mathrm{SO}_{2}$ emission does not at all or only insignificantly affects the growth of species diversity. Furthermore, lichens respond to changes in $\mathrm{SO}_{2}$ concentration with some delay, as quoted by e.g. Seaward and Letrouit-Galinou (1991), clear symptoms of these responses might be visible after 4-5 years.

Cities all over the world have became an object of observations in respect of the process of recolonization by lichens (e.g.: Rosa \& Hawksworth 1981; Hawksworth \&
McManus 1989; Pertti 2001; Isocrono et al. 2007; Larsen et al. 2007; McClenahen et al. 2007).

Apart from urbanized areas, recolonization by lichens against a background of changing habitat conditions, was also analysed in forest areas, both in Poland (inter alia Kiszka 2002), as well as outside the borders of the country (e.g. Wagner et al. 2006).

Global environmental changes, from acidification to an increase of habitats' trophy, as a consequence of fertilization of substrata with nitric compounds brought about spreading of nitrophytic and neutrophytic lichen species (Kriecke \& Feige 2004).

Recolonization by lichens is a response of these organisms to changes in habitat conditions; on the one hand, a decrease in the emission of sulphur and nitrogen oxides can be observed, and on the other hand - the increase of dustiness (e.g.: Seaward \& Letrouit-Galinou 1991; Purvis et al. 2003; Bates 2004; Fałtynowicz 2004; Seaward \& Coppins 2004; Larsen et al. 2007). 
Improvement of the air quality in Poland has begun with certain delay in relation to changes in industrialized Europe. According to Grodzińska and Szarek (1995), as compared to other European countries, Poland is one of the most polluted countries with industrial emissions. At the turn of the 1980s and 1990s, Poland was one of the main producers of $\mathrm{SO}_{2}$, and at that time, the emission of this gas from the Polish territory amounted to over 4 million tons.

According to the report on environmental conditions, since the beginning of the 1990s, a tendency has been observed in Poland for the decreasing concentrations of toxic substances in the atmospheric air, for instance the emission of $\mathrm{SO}_{2}$ was reduced by half at that time (cf. Fałtynowicz 2004).

Impoverishment of lichens' biota in Poland was described in the areas, where lichenological researches have been carried out till the end of the 1990s (e.g.: WilkonMichalska et al. 1988; Kiszka 1993; Kiszka 1999; Śliwa 2000).

Whereas, the effects of the tendency for the decreasing emission of pollutants, observed in Poland since the beginning of the 21 st century, are already evident in the studies on the biota of lichens after 2000 (Kiszka 2002; Fałtynowicz 2004; Kubiak 2005; Adamska 2008).

\section{The study area}

The city of Torun is situated between $52^{\circ} 58^{\prime}$ and $53^{\circ} 04^{\prime}$ of north latitude, and between $18^{\circ} 32^{\prime}$ and $18^{\circ} 43^{\prime}$ of east longitude. Within the current administrative limits, the city covers the area of over $115 \mathrm{~km}^{2}$. According to physical and geographical regionalization of Poland, Torun is situated in the mesoregion of the Torun Valley, the macroregion of the Torun-Eberswalde ice-marginal Valley, included within the subprovince of the South Baltic Lakeland (cf. Andrzejewski \& Kot 2006).

\section{Materials and methods}

Lichenological studies were conducted in 2001-2010. The study area is located within the administrative limits of the city of Torun. Collection of lichens was done from all possible substrata of their occurrence, with particular consideration for epiphytic lichens. The collection was performed in accordance with the system of squares of $1 \times 1 \mathrm{~km}$ ATPOL, modified for lichenological objectives (Cieśliński \& Fałtynowicz 1993). Historical data on the species composition and the occurrence of lichens in the city of Torun from the 1950s and 1980s (Wilkoń-Michalska et al. 1988), as well as modern data, were compiled on cartograms in order to reveal changes in time and space. The identification keys by Purvis et al. (1992) and other monographs were used to identify the collected lichens. The names of lichens are given after Diederich et al. (2010).

\section{Results and discussion}

In Torun, during the last 60 years, since the first lichenological information, at first a considerable impoverishment of lichens' biota was recorded (Wilkoń-Michalska et al. 1988), whereas at present, a reversal process has been observed. Conclusions included in the literature, related to the impoverishment of lichens' biota in Torun, were connected with the progressive dynamic development of the city during this period. Deteriorating environmental conditions had been affecting the quality of life in Torun as long as the late 1990s.

Since 2001, habitat conditions of the city have been significantly improving. The level of $\mathrm{SO}_{2}$ concentrations in Torun considerably decreased over the years, at all measuring points (Wojtczak et al. 2007).

During the on-going lichenological researches in Torun, based on the documented cartographic literature data, the assumption was made about the possibility of lichens' return to their previously occupied sites.

At present, nitrophilous, coniophilous and heliophilous species are spreading in Torun due to changes in the type and concentrations of pollutants. This concerns mainly epiphytic lichens, such as: Phaeophyscia orbicularis, Physcia tenella, Xanthoria candelaria, X. parietina and X. polycarpa. The contribution of these species at particular research sites (squares) is presented in Figure 1. At present, these taxa occur in particularly large numbers in the centre of the city.

The return of Xanthoria polycarpa is a particularly evident example (Fig. 2A). According to Wilkoń-Michalska et al. (1988), in the 1950s, the species was recorded at more than a half of the localities in the centre of Torun, whereas after 30 years, thalli of this lichen were recorded at only 3 sites distant from the city centre. At present, $X$. polycarpa has returned to the previously occupied sites, so the number of sites increased (more that $60 \%$ of the sites) and it spreads over the entire area of the city.

Xanthoria parietina is another species that spreads currently in the area of Torun. This taxon was recorded at 99 sites (more than $73 \%$ of the sites), while in 1980 s, X. parietina was recorded at only 33 sites, far from the industrial centre of the city (Fig. 2B).

For comparison, Kepel (1999) observed that during 40 years, biota of lichens in Poznań underwent a considerable impoverishment. For example in the 1950s, Xanthoria parietina (Fig. 3) occurred in Poznań, similarly like in Torun, in the city centre at most of the sites, while 40 years later, the range of this species shifted towards the city limits. The author drew similar conclusions also regarding the oc- 
currence of Xanthoria polycarpa in the city of Poznań. At that time, no symptoms of recolonization by these species were recorded.

However, in the city of Kielce, similarly like in Torun, spreading of some species was observed during the current lichenological researches, e.g.: Phaeophyscia orbicularis and Xanthoria parietina (Lubek 2010).

Physcia tenella constitutes an example of yet another nitrophilous lichen returning to former occurrence localities in Torun. At present, it covers 107 localities, whereas in the $1980 \mathrm{~s}$, this species was recorded at only 16 sites far from the city centre. Whereas 60 years ago, Physcia tenella occurred, like at present, also in the centre of Torun (Fig. 2C).

For instance, based on the data on the occurrence of lichens during 200 years in the city of Turin, the influence of changes in the habitat conditions in this city has become visible. The following decrease in the atmospheric concentration of $\mathrm{SO}_{2}$ was recorded in Turin - for example, from $2000 \mu \mathrm{g} / \mathrm{m}^{3}$ in 1973 to $53 \mu \mathrm{g} / \mathrm{m}^{3}$ in 1996. At present, nitrophilous species are spreading there like in Toruń (Isocrono et al. 2007).

In the Ruhr Valley, one of the most industrialized areas of Europe, inter alia Physcia tenella and Phaeophyscia orbicularis currently dominate, likewise in Torun. Gradual withdrawal of acidophilous species from this area is also noteworthy, such as toxitolerant Lecanora conizaeoides (Kriecke \& Feige 2004).

So far, no withdrawal of $L$. conizaeoides has been observed in Torun. This taxon occurs at most of the research sites in the town, although still in the 1950s it was one of the rare species.

Apart from nitrophilous species, also sensitive acidophilous species are returning to Torun, such as Parmelia sulcata (Fig. 2D).

Among others, recolonization by Parmelia sulcata was observed also in Paris, where after 100 years, single thalli of this species were recorded (Seaward \& LetrouitGalinou 1991). At present, a similar situation takes place in many towns of Poland, e.g. in the town of Wrocław (Dimos 2002).

One can also talk about the initiated recolonization by Evernia prunastri in Torun. At present, the number of sites in the town, where this species occurs, has considerably increased, but still it has not been recorded in the centre of Torun, where it occurred in large numbers in the 1950s.

In the city of Olsztyn, Kubiak (2005) recorded contemporarily Evernia prunastri at as many as 147 sites, and Fałtynowicz (2004) believes that the return of this species is one of the most spectacular examples of the recolonization by lichens in Poland.
Figure 1. The contribution of nitrophilous species at particular research sites in the city of Toruń in 2001-2010

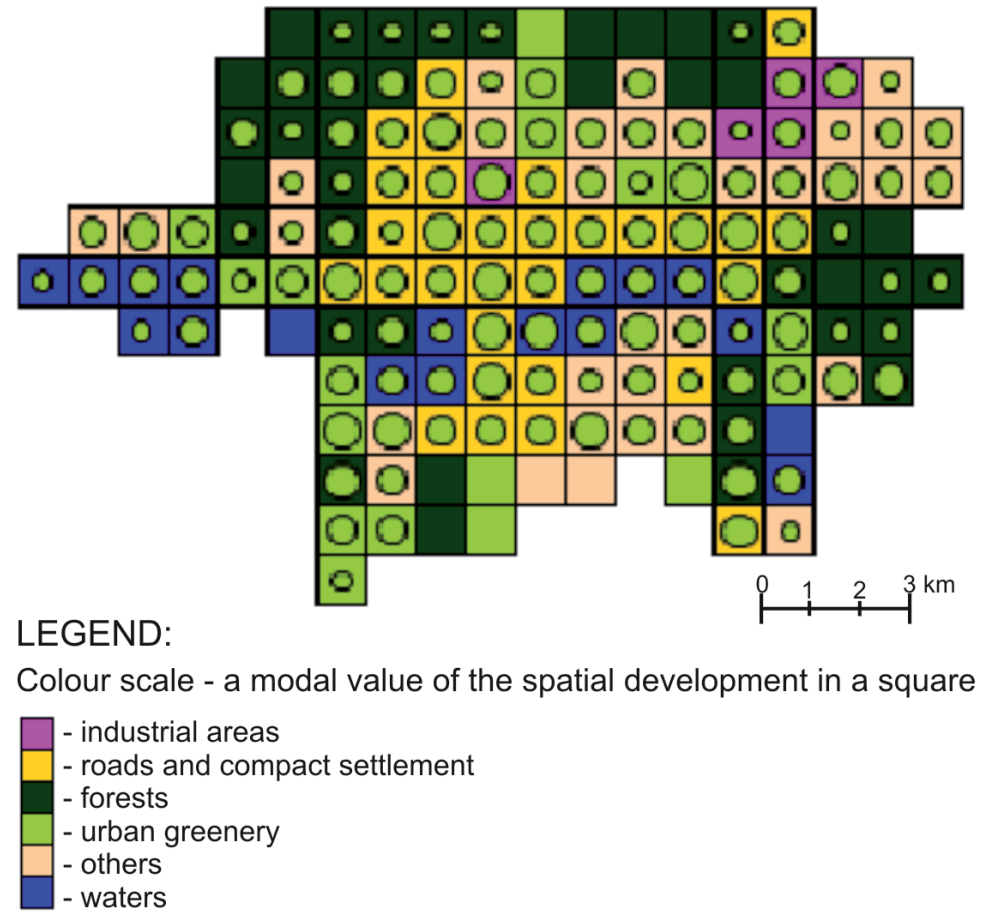

The scale of number of species in a square

$$
\begin{array}{lllllll}
0 & \bigcirc & \bigcirc & \bigcirc \\
0 & 1 & 4 & 10 & 15 & 30 & \text { more than } 30 \text { species }
\end{array}
$$



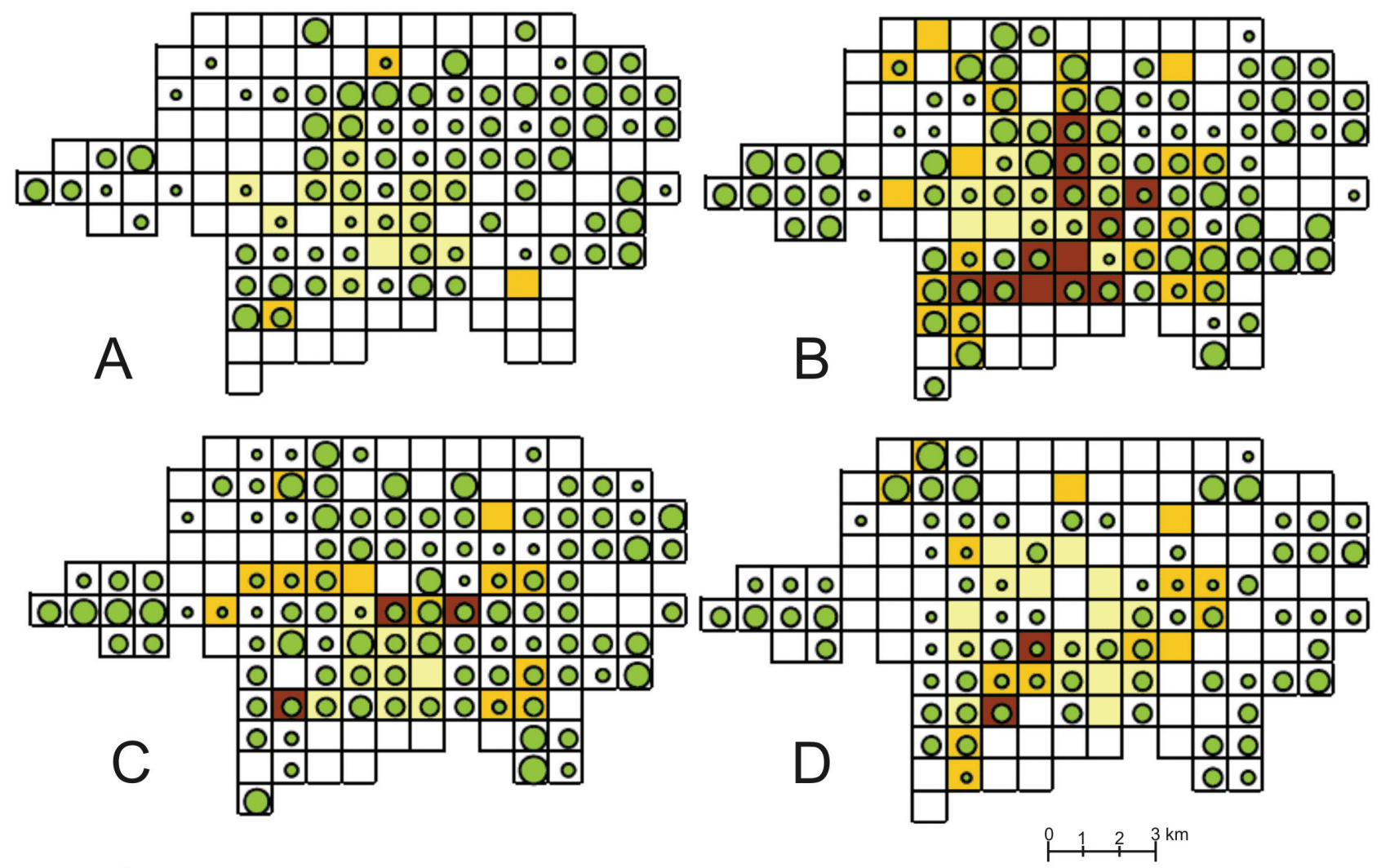

LEGEND:

The colour scale for particular occurrences during the analysed research periods:

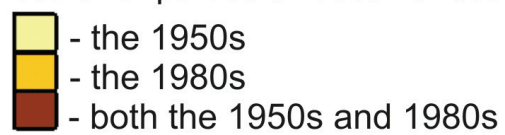

The scale of degrees of cover on all available substrata, expressed in percentage during 2001-2010:

$\circ \circ 0000$

$0 \quad 141015 \quad 30$ more than $30 \%$

Figure 2. The occurrence of lichens (A - Xanthoria polycarpa (Hoffm.) Rieber; B - Xanthoria parietina (L.) Th. Fr.; C - Physcia tenella (Scop.) DC ; D - Parmelia sulcata Taylor) in the area of Torun in the 1950s and 1980s, as well as in 2001-2010 at particular research sites 


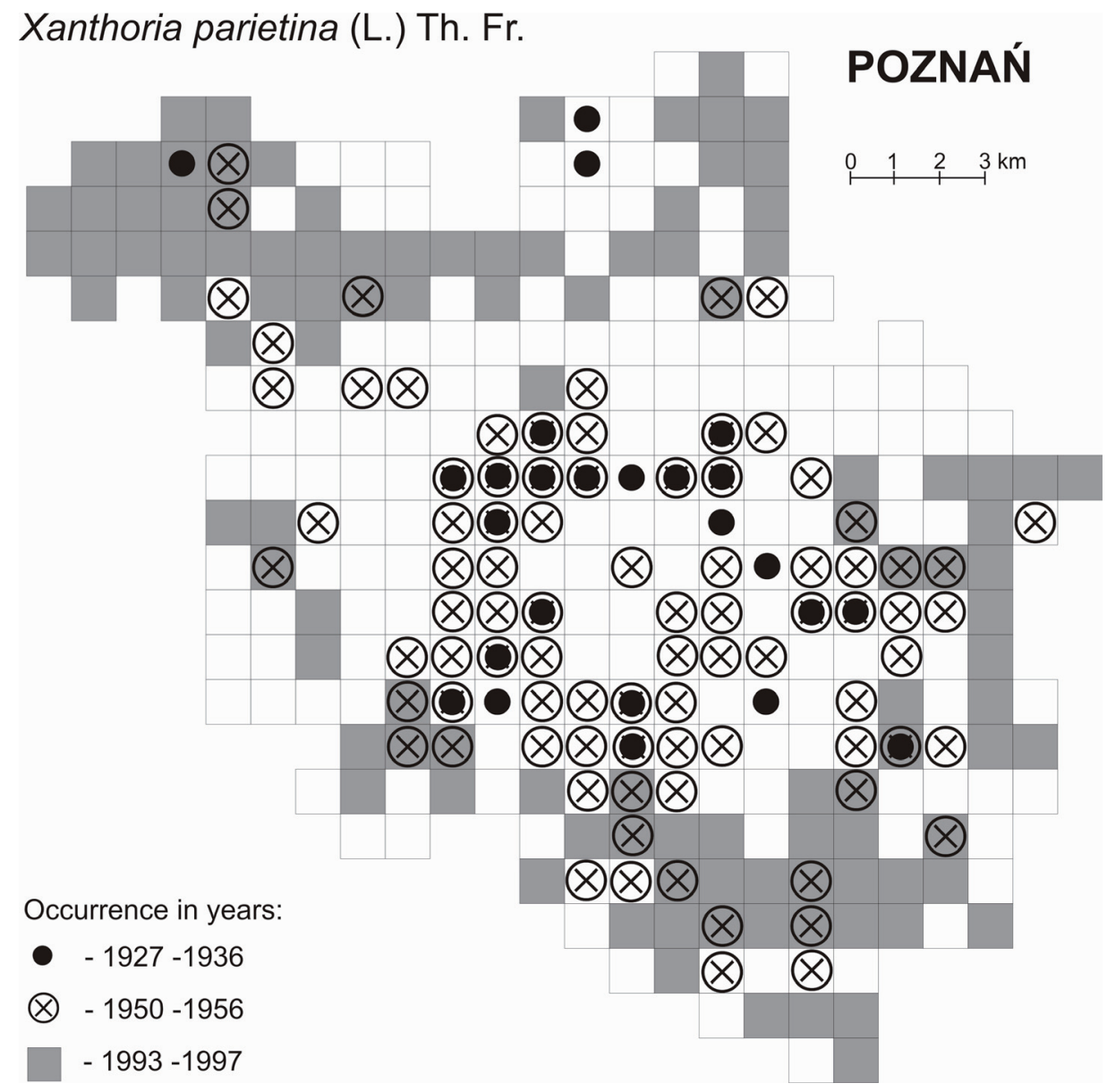

Figure 3. The occurrence of Xanthoria parietina (L.) Th. Fr. in the city of Poznań in 1927-1935, 1950-1956 and 1993-1997 (according to Kepel 1999)

\section{Conclusions}

The process of recolonization by lichens was described in numerous examples in many countries all over the world, recently including also Poland.

The phenomenon of lichens returning to their former sites, against a background of changes in the type and concentrations of pollutants, has been also observed in Toruń.

The most spectacular example is a drop in the concentration of $\mathrm{SO}_{2}$ in the atmospheric air, which results from the implementation of sustainable development principles in the city management.

At present in Torun the process of impoverishment of lichens' biota has been inhibited. Currently, due to eutrophication and alkalization of habitats, nitrophilous, coniophil- ous and heliophilous lichen species become widespread in the town, e.g.: Xanthoria parietina, X. polycarpa.

To summarize, one can state that based on the analysis of the literature data and on-going lichenological researches concerning the species composition and the distribution of lichens in Torun, the first symptoms of recolonization by these organisms were observed in the town.

The obtained data constitute the basis for monitoring the process of returning by individual lichen species to their former sites of occurrence.

\section{Acknowledgements}

I would like to express my gratitude to the anonymous Reviewer for recommendations and comments on the manuscript of this paper. 


\section{References}

Adamska E., 2008, Porosty Torunia na tle warunków siedliskowych miasta [Lichens of Torun in the habitat conditions of the city], Manuscript of the doctoral thesis, Department of Taxonomy and Plant Geography UMK, Toruń.

Andrzejewski L. \& Kot R., 2006, O położeniu Torunia [About localization of Toruń], [in:] L. Andrzejewski, P. Weckwerth, Sz. Burak (eds.), Toruń i jego okolice. Monografia przyrodnicza, [Torun and its surroundings. Nature Monograph], UMK, Toruń: 27-34.

Bates J. W., 2004, Efekty oddziaływań na mszaki i porosty [Effects on bryophytes and lichens], [in:] J. N. B. Bell, M. Treshow (eds.), Zanieczyszczenie powietrza a życie roślin, [Air pollution and plant life], Wyd. Naukowo-Techniczne, Warszawa: 345-384.

Cieśliński S. \& Fałtynowicz W., 1993, Od redakcji [Note from editors], [in:] S. Cieśliński, W. Fałtynowicz (eds.), Atlas rozmieszczenia geograficznego porostów w Polsce cz. I. [Atlas of the Geographical Distribution of lichens in Poland, Part I.], W. Szafer Institute of Botany, Polish Academy of Sciences, Kraków: 7-9.

Conti M. E. \& Cecchetti G., 2001, Biological monitoring: lichens as bioindicators of air pollution assessment a review, Environmental Pollution 114: 471-492.

Diederich P., Ertz D., Stapper N., Sérusiaux E. \& Ries C., 2010, The lichens and lichenicolous fungi of Belgium, Luxembourg and northern France, URL: http://www. lichenology.info.

Dimos M., 2002, Porosty Parku Szczytnickiego we Wrocławiu, Praca Licencjacka, Zakład Systematyki i Fitosocjologii Uniwersytetu Wrocławskiego [Lichens of the Szczytnicki Park in Wrocław, Manuscript of the BSc thesis, Department of Taxonomy and Phytosociology of the Wrocław University], Wrocław.

Fałtynowicz W., 1995, Wykorzystanie porostów do oceny zanieczyszczenia powietrza. Zasady, metody, klucze do oznaczania wybranych gatunków [The use of lichens for the assessment of air pollution. Principles, methods, identification keys for selected species], Centrum Edukacji Ekologicznej Wsi, Krosno.

Fałtynowicz W., 2004, Rekolonizacja przez porosty - optymistyczny trend $\mathrm{w}$ stanie środowiska [Lichen recolonization - optimistic trend in state of the environment], [in:] M. Kejna, A. Uscka (eds.), Zintegrowany monitoring środowiska przyrodniczego. Funkcjonowanie i monitoring geoekosystemów w warunkach narastającej antropopresji [Integrated Monitoring of the Natural Environment. Functioning and monitoring of geoecosystems in the growing human activity conditions], Biblioteka Monitoringu Środowiska, Toruń: 321-325.
Grodzińska K. \& Grey G., 1995, Skażenie środowiska Polski na tle Europy [Contamination of the environment in Poland as compared to Europe], Wiad. Bot. 39 (1/2): 31-38.

Hawksworth D. L. \& McManus P. M., 1989, Lichen recolonization in London under conditions of rapidly falling sulphur dioxide levels, and the concept of zone skipping, Bot. Journal of the Linnean Society 100: 99-109.

Isocrono D., Matteucci E., Ferrarese A., Pensi E. \& Piervittori R., 2007, Lichen colonization in the city of Turin (N Italy) based on current and historical data, Environmental Pollution 145: 258-265.

Kepel A., 1999, Porosty Poznania jako wskaźniki zanieczyszczenia atmosfery [Lichens in the city of Poznan as indicators of atmospheric pollution], Manuscript of the doctoral thesis, Department of Plant Taxonomy UAM, Poznań.

Kiszka J., 1993, Wpływ emisjii miejsko-przemysłowych [Influence of urban-industrial emissions on the flora of lichens in Upper Silesia and its surroundings], Studia Ośrod. Dok. Fizjogr. 21: 183-215.

Kiszka J., 1999, Porosty (Lichenes) oraz warunki bioekologiczne Przemyśla [Lichens and bioecological conditions of Przemyśl], Arboretum Bolestraszyce 6: 1-86.

Kiszka J., 2002, Estimation of the changes in the lichen flora of the Niepołomice Forest (Southern Poland) in the years 1959-2000, Ecological Questions 1/2002: 87-96.

Kriecke R. \& Feige G. B., 2004, Changes in epiphytic lichen flora in Urban environments, [in:] P. Lambley, P. Wolseley, (eds.), Lichens in a Changing Pollution Environment, English Nature Research Report No. 525, Peterborough: 27-30.

Kubiak D., 2005, Lichens and lichenicolous fungi of Olsztyn town (NE Poland), Acta Mycol. 40 (2): 293-332.

Larsen R. S., Bell J. N. B., James P. W., Chimonides P. J., Rumsey F. J., Tremper A. \& Purvis O. W., 2007, Lichen and bryophyte distribution on oak in London in relation to air pollution and bark acidity, Environ. Pollution 146: $332-340$.

Łubek A., 2010, Ocena stanu środowiska przyrodniczego Kielc na podstawie bioty porostów epifitycznych [The estimation of environment of Kielce town on the basis of the epiphytic lichen biota], Fragm. Flor. Geobot. 17 (1): 149-163.

McClenahen J. R., Davis D. D. \& Hutnik R. J., 2007, Macrolichens as biomonitors of air-quality change in Western Pennsylvania, Northeastern Naturalist 14 (1): 15-26.

Nash III T. H., 2008, Lichen sensitivity to air pollution, [in:] T. H. Nash III (ed.), Lichen Biology, second Edition, Cambridge Univ. Press: 299-314. 
Pertti R., 2001, Changes in urban lichen diversity after a fall in sulphur dioxide levels in the city of Tampere, SW Finland, Ann. Zool. Fenn. 38 (4): 295-304.

Purvis O. W., Chimonides J., Din V., Erotokritou L., Jeffries T., Jones G. C., Louwhoff S., Read H. \& Spiro B., 2003, Which factors are responsible for the changing lichens floras of London?, The Science of the Total Environment 310: 179-189.

Purvis O. W., Coppins B. J., Hawksworth D. L., James P. W. \& Moore D. M., 1992, The lichen flora of Great Britain and Ireland. Natural History Museum \& British Lichen Society, London.

Rose C. I. \& Hawksworth D. L., 1981, Lichen recolonization in London's cleaner air, Nature 289: 289-292.

Seaward M. R. D., 1997, Urban deserts bloom: a lichen renaissance, [in:] L. Kappen (ed.), New species and novel aspects in lichenology and physiology of lichens, Bibl. Lichenol. 67: 297-309.

Seaward M. R. D. \& Coppins, B. J., 2004, Lichens and hypertrophication, Contributions to Lichenology: 561572.

Seaward M. R. D. \& Letrouit-Galinou M. A., 1991, Lichen recolonozation on trees in the Jardin du Luxembourg, Paris, Lichenologist 23 (2): 181-186.
Showman R. E., 1981, Lichen recolonization following air quality improvement, The Bryologist 84 (4): 492497.

Śliwa L., 2000, Lichenoindykacja zmian środowiska naturalnego Beskidu Sądeckiego [Lichenoindication of transformations in the natural environment of Beskid Sądecki Mts], Ochrona Przyrody 57: 41-49.

Wagner H. H., Werth S., Kalwij J. M., Boli J. C. \& Scheidegger Ch., 2006, Modelling forest recolonization by an epiphytic lichen using a landscape genetic approach, Landscape Ecology 21: 849-865.

Wilkoń-Michalska J., Glazik N. \& Kalińska A., 1988, Porosty miasta Torunia [The lichens of Toruń town], Acta Univ. Nicolai Copernici 63, Biologia 29: 209-253.

Wojtczak H., Solarczyk A., Hildebrandt K., Jankowski J. \& Piotrowiak P., 2007, Stan środowiska miasta Torunia w 2006 roku [Environmental conditions of the city of Toruń in 2006], Wojewódzki Inspektorat Ochrony Środowiska w Bydgoszczy, Delegatura w Toruniu [Provincial Inspectorate of Environmental Protection in Bydgoszcz, Branch Office in Toruń], www.wios.bydgoszcz.pl/pdf/torun2006.pdf. 